\title{
Dose-response association between physical activity and clustering of modifiable cardiovascular risk factors among 26,093 Chinese adults
}

\author{
Rui Shi ${ }^{1}$, Yamei Cai ${ }^{2}$, Rui Qin ${ }^{2}$, Yang Yan $^{3^{*}}$ (D) and Dahai Yu ${ }^{4}$
}

\begin{abstract}
Background: There is uncertain evidence in the dose-response association between overall physical activity levels and clustering of cardiovascular diseases modifiable risk factors (CVDMRF) in Chinese adults. This study examined the hypothesis whether inverse dose-response association between overall physical activity levels and clustering of CVDMRF in Chinese adults exist.

Methods: Twenty-six thousand ninety-three Chinese adult participants were recruited by two independent surveys in Nanjing and Hefei during 2011 to 2013, from random selected households provided smoking, glucose, lipids, anthropometric, and blood pressure measurements. Logistic regression model was applied to examine the doseresponse association between overall physical activity (measured by metabolic equivalent task (MET)- minutes per week) and having $\geq 1, \geq 2$, and $\geq 3$ CVDMRF (dyslipidemia, hypertension, diabetes, cigarette smoking, and overweight).
\end{abstract}

Results: An inverse linear dose-response relationship between physical activity and clustering of CVDMRF was identified, as increased physical activity levels are associated with lower odds of having clustering of CVDMRF. The adjusted odds ratio ( $95 \%$ confidence interval) of having $\geq 1, \geq 2$, and $\geq 3$ CVRF for moderate physical activity group and high physical activity group was 0.88 (0.79 to 0.98 ) and 0.88 (0.79 to 0.99$), 0.85$ (0.78 to 0.92 ) and 0.85 (0.78 to $0.92), 0.84$ (0.76 to 0.91 ) and 0.81 (0.74 to 0.89 ), respectively, with low physical activity as reference group.

Conclusions: Among Chinese adults, physical activity level inversely associates with clustering of CVDMRF, especially in those aged 35-54 years. Health promotion including improve physical activity should be advocated. The potential role of physical activity in the clustering of CVDMRF warrants further validation.

Keywords: Physical activity, Cardiovascular diseases, Cardiovascular risk factor

\footnotetext{
*Correspondence: yyangxjtu77@gmail.com

${ }^{3}$ Department of Cardiovascular surgery, The First Affiliated Hospital of Xi'an Jiaotong University, Xi'an 713300, China

Full list of author information is available at the end of the article
}

(c) The Author(s). 2020 Open Access This article is licensed under a Creative Commons Attribution 4.0 International License, which permits use, sharing, adaptation, distribution and reproduction in any medium or format, as long as you give appropriate credit to the original author(s) and the source, provide a link to the Creative Commons licence, and indicate if changes were made. The images or other third party material in this article are included in the article's Creative Commons licence, unless indicated otherwise in a credit line to the material. If material is not included in the article's Creative Commons licence and your intended use is not permitted by statutory regulation or exceeds the permitted use, you will need to obtain permission directly from the copyright holder. To view a copy of this licence, visit http://creativecommons.org/licenses/by/4.0/ The Creative Commons Public Domain Dedication waiver (http://creativecommons.org/publicdomain/zero/1.0/) applies to the data made available in this article, unless otherwise stated in a credit line to the data. 


\section{Background}

Cardiovascular diseases (CVD) as the leading death cause has affected 290 million Chinese people with CVD and caused 3.5 million annual death [1]. It is also projected that annual cardiovascular events will increase by more than $50 \%$ by 2030 in China based on the current the aging population and the growth of population [2]. Different from the developed countries in which the prevalence of some CVD modifiable risk factors has decreased, the prevalence of CVD modifiable risk factors has increased in developing countries. In particular, major modifiable risk factors: current smoking, overweight, diabetes, hypertension and dyslipdaemia have been found very common in Chinese adults [3]. For example, it has been estimated that $80.5,45.9$, and $17.2 \%$ of Chinese adults $\operatorname{had} \geq 1, \geq 2$, and $\geq 3$ above CVD modifiable risk factors [3].

Emerging evidence suggests physical activity may be relevant to circulating metabolites, including lipoproteins, lipids, and glucose, which have been associated with risk of CVD $[4,5]$. However, few studies have addressed the association between physical activity and clustering of CVD modifiable risk factors, particularly in Chinese population. The goal of this study was to quantify the dose-response association between physical activity level and having a clustering of 1 or more, 2 or more, and 3 or more of CVD modifiable risk factors: dyslipidemia, hypertension, diabetes, current smoking, and overweight in Chinese adults.

\section{Methods}

\section{Data setting}

Two independent surveys were implemented in two Chinese places: Nanjing and Hefei [6]. The Nanjing Community Cardiovascular Risk Survey was processed by random cluster sampling [7], between 2011 and 2013, among adults resident in 6 communities of Nanjing, the capital city of Jiangsu Province in China. In every Nanjing community, one township or street district was chosen at random. Six thousand four hundred forty-five households in the chosen town or street were incorporated with only one adult aged 20 years and over sampled from every household, without replacement. Five thousand eight hundred twenty-four participants completed their clinical examination and survey (response rate: 90\%). The Hefei Community Cardiovascular Risk Survey was also implemented by a random cluster sampling [6], between 2012 and 2013 among the adults residents in 10 rural areas of Hefei, the capital city of Anhui Province in China. In every rural area of Hefei, one township was randomly chosen. Twenty-two thousand thirty-two households in the chosen rural town were all incorporated with only one adult aged 20 years and over sampled from every household, without replacement. Twenty thousand two hundred sixtynine participants completed their clinical examination and survey (response rate: 92\%). Ethics approval of this study was acquired from the Institutional Review Board of Jiangsu
Province Hospital on Integration of Chinese and Western Medicine (approval number 11-006). Signed, Informed consent was obtained from all study participants.

\section{Clinical measurements}

Both in Nanjing and Hefei surveys, research questionnaires were completed by trained research staff through face-to-face interviews. Question items covered age, gender, race, smoking status, and known diabetes. Participants who reported having smoked $\geq 100$ cigarettes during their lifetime were classified as current smokers if they answered affirmatively to the question, "Do you smoke cigarettes now?" [3].

Both in Nanjing and Hefei surveys, body measurements and blood pressure measures were taken three times on the same day by a standardized methodology in the local clinical center and the mean of the two closest recordings was recorded as the final measurement. Body measurements including weight, height and waist circumference were measured by using a vertical weight scale and metric scale. Study participants' weight were measured to the nearest 10th of a kilogram with wearing light indoor clothing without shoes. Study participants' height was measured to the nearest 10th of a centimeter without wearing shoes. Both in Nanjing and Hefei surveys, above measurements were made by trained observers who were all asked to attend a training session to learn the standardized protocol of measurement techniques [8]. Study participants' body mass index was calculated by their body weight (unit: $\mathrm{kg}$ ) divided by the square of their height (unit: meter). Study participants with $\mathrm{BMI} \geq 25 \mathrm{~kg} / \mathrm{m}^{2}$ was defined as overweight [9].

Blood samples were collected for all participants after an overnight fasting for at least $10 \mathrm{~h}$ by trained nurse. The fasting time was verified prior to collecting the blood specimen. Participants who had not fasted for at least $10 \mathrm{~h}$ did not have their blood drawn.

Plasma samples for measuring glucose were collected using vacuum blood collection tubes containing anticoagulant sodium fluoride and the serum samples for measuring lipid profile and creatinine were collected using vacuum blood collection tubes not containing sodium fluoride. Fasting blood specimens collected in Nanjing were processed at the examination center (Nanjing) for urban population and fasting blood specimens collected in Hefei rural population were shipped by air to Nanjing examination centre. All specimens were stored at $-70{ }^{\circ} \mathrm{C}$ until laboratory assays were performed. Plasma glucose, serum creatinine, and serum lipid levels were measured by automated analyser (Olympus AU600 autoanalyser (Olympus Optical, Tokyo, Japan)). Participants who currently accepting anti-hypertensive treatment or having a $140 \mathrm{mmHg}$ and over of a mean systolic blood pressure (SBP) and/or a $90 \mathrm{mmHg}$ and over of 
mean diastolic blood pressure (DBP) were defined as having hypertension $[10,11]$. Dyslipidemia was defined as currently accepting lipid-lowering therapy or having $\geq 1$ of the higher lipid profile measurements as:

total cholesterol $\geq 5.2 \mathrm{mmol} / \mathrm{L}$, triglycerides $\geq 1.7 \mathrm{mmol} /$ L, HDL cholesterol $<1.0 \mathrm{mmol} / \mathrm{L}$, or LDL cholesterol $\geq 3.4 \mathrm{mmol} / \mathrm{L}$ [12]. Participants currently accepting antidiabetic therapies (insulin or oral hypoglycemic agents) or having a high measurement of fasting glucose (fasting plasma glucose level $\geq 7.0 \mathrm{mmol} / \mathrm{L}$ ) was defined as having diabetes [13].

\section{Physical activity measurements}

International Physical Activity Questionnaire was used to collect physical activity information on household, transport, and job, as well as those on leisure-time, sports and recreation. Information about $\geq 10$ min specific activities by the intensity, daily duration, and total weekdays during the prior week was acquired from participants [14]. Metabolic equivalent task (MET)- minutes every week (Met Score) were generated from the raw data. Met Score was also grouped into 3 levels: low physical activity group (who having < 600 MET-min/ week), moderate physical activity group (who having 600-3000 MET-min/week) and high physical activity group (who having $\geq 3000 \mathrm{MET}$-min/week) [15]. The
MET Score was transformed to its square root due to the non-normality of distribution.

\section{Statistical analysis}

The median and interquartile range was presented for continuous variables. Transformed Met Score (square root of Met Score) were compared by t test. Categorical variables were presented as count and percentages, and their difference across categories were examined by Chisquare test. Multivariable Logistic regression model was applied to assess the association between the transformed Met Score and odds of having $\geq 1, \geq 2$, and $\geq 3$ major CVD modifiable risk factors by i) quantifying the odds ratio (OR) by increase of 1 standard deviation (SD) of transformed Met Score; ii) quantifying the OR by comparing the physical activity moderate and high level with the low level. Dose-response relationship between the transformed Met Score and odds of having $\geq 1, \geq 2$, and $\geq 3$ major CVD modifiable risk factors was also examined by natural cubic spline model.

All statistical analyses were processed using STATA MP 15.0. All $P$-values were estimated by two-tailed tests and a $P$-value $<0.05$ was taken as significance level.

\section{Results}

The characteristics of study participants in Nanjing survey sample, Hefei survey sample and the pooled survey

Table 1 Characteristics of study participants

\begin{tabular}{|c|c|c|c|}
\hline Characteristics & Survey-1 (Nanjing) & Survey-2 (Hefei) & Pooled data \\
\hline Participants, n & 5824 & 20,269 & 26,093 \\
\hline Age, years & $52.0(43.0$ to 59.0$)$ & $51.0(43.0$ to 58.0$)$ & $51.0(43.0$ to 58.0$)$ \\
\hline Women, n (\%) & $3278(56.3)$ & $11,905(58.7)$ & $15,183(58.2)$ \\
\hline Current smoking, n (\%) & $1571(28.0)$ & $4687(23.3)$ & $6258(24.0)$ \\
\hline Hypertension, n (\%) & $2259(38.8)$ & $9228(45.5)$ & $11,487(44.0)$ \\
\hline Type 2 diabetes, n (\%) & $472(8.1)$ & $1832(9.0)$ & $2304(8.8)$ \\
\hline Body mass index, $\mathrm{kg} / \mathrm{m}^{2}$ & $23.6(21.4$ to 26.1$)$ & 24.1 (21.8 to 26.5$)$ & $24.0(22.1$ to 26.8$)$ \\
\hline Waist circumference, $\mathrm{cm}$ & $80.0(73.3$ to 87.0$)$ & 81.6 (74.3 to 88.7) & 81.3 (74.0 to 88.4$)$ \\
\hline Systolic blood pressure, $\mathrm{mmHg}$ & 128 (116 to 143$)$ & $132(120$ to 148$)$ & $131(119$ to 147$)$ \\
\hline Diastolic blood pressure, $\mathrm{mmHg}$ & 80.5 (73.5 to 88.5$)$ & 82.5 (75.0 to 90.5$)$ & $82.0(75.0$ to 90.0$)$ \\
\hline Fasting glucose, mmol/L & $5.4(4.9$ to 5.9$)$ & 5.3 (4.8 to 5.2$)$ & $5.3(4.8$ to 5.8$)$ \\
\hline Triglyceride, mmol/L & $1.2(0.8$ to 1.7$)$ & $1.3(0.9$ to 1.8$)$ & $1.2(0.9$ to 1.8$)$ \\
\hline Total cholesterol, mmol/L & $4.4(3.9$ to 4.9$)$ & 4.6 (4.0 to 5.2$)$ & $4.5(4.0$ to 5.1$)$ \\
\hline High density lipoprotein cholesterol, mmol/L & $1.3(1.1$ to 1.5$)$ & $1.3(1.1$ to 1.5$)$ & $1.3(1.1$ to 1.5$)$ \\
\hline Low density lipoprotein cholesterol, mmol/L & $2.4(2.0$ to 2.9$)$ & $2.6(2.2$ to 3.1$)$ & $2.5(2.1$ to 3.0$)$ \\
\hline Dyslipidaemia, n (\%) & $2583(44.4)$ & $10,463(51.6)$ & $13,046(50.0)$ \\
\hline Overweight, n (\%) & $2341(40.2)$ & $9187(45.3)$ & $11,528(44.2)$ \\
\hline Having $\geq 1$ CVD modifiable risk factor, $\mathrm{n}(\%)$ & $4692(80.6)$ & $17,118(84.5)$ & $21,810(83.6)$ \\
\hline Having $\geq 2$ CVD modifiable risk factors, $\mathrm{n}(\%)$ & $2914(50.0)$ & $11,421(56.4)$ & $14,335(54.9)$ \\
\hline Having $\geq 3$ CVD modifiable risk factors, $\mathrm{n}(\%)$ & $1275(21.9)$ & $5422(26.8)$ & $6697(25.7)$ \\
\hline
\end{tabular}

Continuous variables were presented as median (interquartile range); categorical variables were presented as number (percentage) 
samples are presented in Table 1. The prevalence of current smoking, overweight, dyslipidemia, hypertension, and diabetes was $24.0,44.2,50.0,44.0$ and $8.0 \%$ in the pooled survey sample, respectively. The prevalence of each CVRF above was 28.0, 40.2, 44.4, 38.8, and $8.1 \%$ in Nanjing survey sample and 23.3, 45.3, 51.6, 45.5 and $9.0 \%$ in Hefei sample, respectively. The prevalence of having $\geq 1, \geq 2$ and $\geq 3$ CVD modifiable risk factors was 83.6, 54.9 and $25.7 \%$ in the pooled survey sample, respectively. The prevalence of having $\geq 1, \geq 2$ and $\geq 3$ CVD modifiable risk factors was higher in Hefei survey sample comparing with Nanjing sample, as $84.5,56.4$, and $26.8 \%$ in Hefei survey sample and 80.6, 50.0 and $21.9 \%$ in Nanjing survey sample, respectively.

The distribution of physical activity levels (transformed Met Score) was presented in Table 2 by the status of clustering of CVD modifiable risk factors. Participants with clustering of CVD modifiable risk factors was more likely to have lower physical activity comparing with those without clustering of CVD modifiable risk factors, as the median (IQR) of transformed Met Score was 48.9 (33.8 to 70.2), 47.8 (33.6 to 70.7) and 46.2 (32.9 to 69.1 ) among those with $\geq 1, \geq 2$ and $\geq 3$
CVRF; 50.0 (34.1 to 71.9), 50.2 (34.1 to 72.0), and 50.1 (34.2 to 72.0 ) among those without $\geq 1, \geq 2$ and $\geq 3$ CVD modifiable risk factors, respectively. Similarly, significantly lower physical activity was found among participants with clustering of CVD modifiable risk factors comparing with those without clustering of CVD modifiable risk factors in each survey sample and by sex. In the age-stratified analysis, the significant difference was found in age group 35-44 years and 45-54 years.

The dose-response association between transformed Met Score and adjusted odds ratio (OR) of having $\geq 1, \geq 2$ and $\geq 3$ CVD modifiable risk factors was presented in Fig. 1. Linear dose-response relationships were found in overall, by survey, sex, and age groups (non-linear test: all $P$-value $>0.05$ ).

As presented in Table 3, the adjusted OR of having $\geq 1$, $\geq 2$ and $\geq 3$ CVD modifiable risk factors by per SD increase was 0.98 (0.94 to 1.01 ), 0.96 (0.93 to 0.99 ) and 0.93 (0.90 to 0.96 ), respectively. In the site-specific analysis, the significant adjusted OR of having $\geq 1, \geq 2$, and $\geq$ 3 CVD modifiable risk factors was found in Nanjing survey, Hefei survey and both surveys. In the sex-specific analysis, adjusted OR of having $\geq 1$ CVD modifiable risk

Table 2 Distribution of physical activity levels by cardiovascular disease risk factors clustering status among Chinese adults

\begin{tabular}{|c|c|c|c|c|c|c|c|c|c|}
\hline \multirow[b]{2}{*}{$\begin{array}{l}\text { Met Score, median (Inter- } \\
\text { quartile range) }\end{array}$} & \multicolumn{2}{|c|}{$\begin{array}{l}\text { Having } \geq 1 \text { CVD modifiable } \\
\text { risk factor }\end{array}$} & \multirow[t]{2}{*}{$P$} & \multicolumn{2}{|c|}{$\begin{array}{l}\text { Having } \geq 2 \text { CVD modifiable } \\
\text { risk factors }\end{array}$} & \multirow[t]{2}{*}{$P$} & \multicolumn{2}{|c|}{$\begin{array}{l}\text { Having } \geq 3 \text { CVD modifiable } \\
\text { risk factors }\end{array}$} & \multirow[t]{2}{*}{$P$} \\
\hline & Yes & $\mathrm{No}$ & & Yes & No & & Yes & No & \\
\hline Overall & $\begin{array}{l}48.9(33.8 \text { to } \\
70.2)\end{array}$ & $\begin{array}{l}50.0(34.1 \text { to } \\
71.9)\end{array}$ & 0.017 & $\begin{array}{l}47.8(33.6 \text { to } \\
70.7)\end{array}$ & $\begin{array}{l}50.2(34.1 \text { to } \\
72.0)\end{array}$ & 0.003 & $\begin{array}{l}46.2(32.9 \text { to } \\
69.1)\end{array}$ & $\begin{array}{l}50.1(34.2 \text { to } \\
72.0)\end{array}$ & $\begin{array}{l}< \\
0.001\end{array}$ \\
\hline \multicolumn{10}{|l|}{ Survey site } \\
\hline Nanjing & $\begin{array}{l}44.2(29.2 \text { to } \\
68.0)\end{array}$ & $\begin{array}{l}47.1(31.0 \text { to } \\
69.3)\end{array}$ & 0.028 & $\begin{array}{l}43.5(28.5 \text { to } \\
67.1)\end{array}$ & $\begin{array}{l}45.7(30.5 \text { to } \\
69.2)\end{array}$ & 0.013 & $\begin{array}{l}43.0(27.6 \text { to } \\
64.6)\end{array}$ & $\begin{array}{l}45.4(30.2 \text { to } \\
69.3)\end{array}$ & 0.003 \\
\hline Hefei & $\begin{array}{l}49.6(35.3 \text { to } \\
71.9)\end{array}$ & $\begin{array}{l}51.3(35.5 \text { to } \\
72.2)\end{array}$ & 0.043 & $\begin{array}{l}50.2(35.4 \text { to } \\
71.3)\end{array}$ & $\begin{array}{l}51.2(35.5 \text { to } \\
72.7)\end{array}$ & 0.002 & $\begin{array}{l}50.0(34.5 \text { to } \\
69.8)\end{array}$ & $\begin{array}{l}51.4(35.5 \text { to } \\
72.7)\end{array}$ & $\begin{array}{l}< \\
0.001\end{array}$ \\
\hline \multicolumn{10}{|l|}{ Sex } \\
\hline Male & $\begin{array}{l}48.3(32.5 \text { to } \\
72.7)\end{array}$ & $\begin{array}{l}51.4(33.5 \text { to } \\
76.1)\end{array}$ & 0.010 & $\begin{array}{l}47.0(32.3 \text { to } \\
71.9)\end{array}$ & $\begin{array}{l}50.0(33.2 \text { to } \\
74.9)\end{array}$ & 0.002 & $\begin{array}{l}46.1(31.5 \text { to } \\
70.2)\end{array}$ & $\begin{array}{l}50.0(33.3 \text { to } \\
74.4)\end{array}$ & 0.002 \\
\hline Female & $\begin{array}{l}49.6(34.2 \text { to } \\
68.2)\end{array}$ & $\begin{array}{l}50.0 \text { (43.6 to } \\
71.0)\end{array}$ & 0.183 & $\begin{array}{l}48.3 \text { (34.9 to } \\
69.2)\end{array}$ & $\begin{array}{l}51.4 \text { (34.6 to } \\
71.0)\end{array}$ & 0.012 & $\begin{array}{l}48.1 \text { (34.6 to } \\
68.2)\end{array}$ & $\begin{array}{l}50.6 \text { (34.7 to } \\
71.0)\end{array}$ & 0.003 \\
\hline \multicolumn{10}{|l|}{ Age group } \\
\hline$<35$ years & $\begin{array}{l}46.6(30.5 \text { to } \\
62.0)\end{array}$ & $\begin{array}{l}47.3 \text { (33.4 to } \\
68.9)\end{array}$ & 0.098 & $\begin{array}{l}44.4(25.8 \text { to } \\
62.2)\end{array}$ & $\begin{array}{l}47.3 \text { (35.5 to } \\
86.0)\end{array}$ & 0.072 & $\begin{array}{l}48.3(17.8 \text { to } \\
63.4)\end{array}$ & $\begin{array}{l}47.3 \text { (32.9 to } \\
93.1)\end{array}$ & 0.098 \\
\hline $35-44$ years & $\begin{array}{l}48.8 \text { (32.4 to } \\
73.2)\end{array}$ & $\begin{array}{l}49.3 \text { (33.5 to } \\
75.3)\end{array}$ & 0.047 & $\begin{array}{l}47.9 \text { (31.3 to } \\
73.2)\end{array}$ & $\begin{array}{l}49.3 \text { (33.5 to } \\
75.1)\end{array}$ & 0.016 & $\begin{array}{l}46.7 \text { (30.0 to } \\
73.6)\end{array}$ & $\begin{array}{l}49.6 \text { (33.2 to } \\
74.8)\end{array}$ & 0.037 \\
\hline $45-54$ years & $\begin{array}{l}48.5(34.5 \text { to } \\
72.7)\end{array}$ & $\begin{array}{l}51.0(35.5 \text { to } \\
73.5)\end{array}$ & 0.036 & $\begin{array}{l}47.3 \text { (34.8 to } \\
72.9)\end{array}$ & $\begin{array}{l}50.8 \text { (34.5 to } \\
73.4)\end{array}$ & 0.026 & $\begin{array}{l}49.4(33.4 \text { to } \\
71.6)\end{array}$ & $\begin{array}{l}51.4(35.1 \text { to } \\
73.9)\end{array}$ & 0.021 \\
\hline $55-64$ years & $\begin{array}{l}49.1(33.3 \text { to } \\
67.9)\end{array}$ & $\begin{array}{l}50.0(34.4 \text { to } \\
68.7)\end{array}$ & 0.056 & $\begin{array}{l}50.0(32.4 \text { to } \\
67.3)\end{array}$ & $\begin{array}{l}50.3 \text { (34.3 to } \\
69.1)\end{array}$ & 0.072 & $\begin{array}{l}49.1(32.2 \text { to } \\
67.5)\end{array}$ & $\begin{array}{l}50.2 \text { (34.6 to } \\
69.4)\end{array}$ & 0.063 \\
\hline $65-74$ years & $\begin{array}{l}49.5 \text { (34.0 to } \\
65.1)\end{array}$ & $\begin{array}{l}50.0(32.9 \text { to } \\
67.7)\end{array}$ & 0.062 & $\begin{array}{l}48.9 \text { (33.9 to } \\
65.1)\end{array}$ & $\begin{array}{l}49.8 \text { (34.0 to } \\
65.8)\end{array}$ & 0.083 & $\begin{array}{l}49.1(33.7 \text { to } \\
65.4)\end{array}$ & $\begin{array}{l}50.4(35.3 \text { to } \\
64.9)\end{array}$ & 0.078 \\
\hline$\geq 75$ years & $\begin{array}{l}49.7(29.4 \text { to } \\
68.1)\end{array}$ & $\begin{array}{l}50.1 \text { (43.7 to } \\
89.6)\end{array}$ & 0.056 & $\begin{array}{l}48.9(27.9 \text { to } \\
68.1)\end{array}$ & $\begin{array}{l}49.8 \text { (36.3 to } \\
78.4)\end{array}$ & 0.076 & $\begin{array}{l}46.2(24.5 \text { to } \\
53.9)\end{array}$ & $\begin{array}{l}49.2 \text { (39.5 to } \\
79.2)\end{array}$ & 0.061 \\
\hline
\end{tabular}



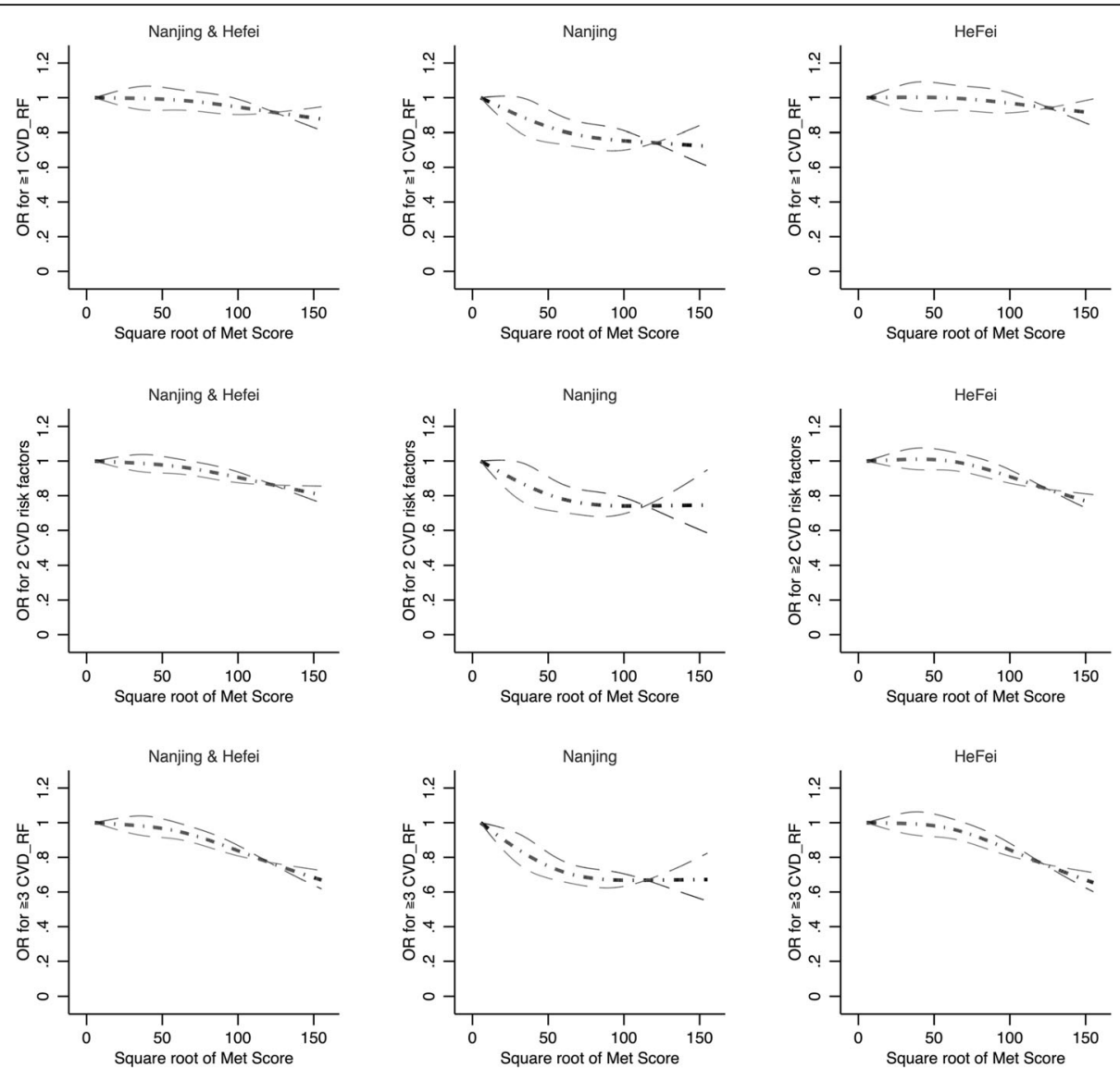

Fig. 1 Adjusted dose-response relationship between Met Scores and odds of having $\geq 1,2,3$ cardiovascular disease risk factors among Chinese adults. In the pooled dataset, sex, age group and survey site were adjusted; in the survey site specific dataset, sex and age group were adjusted

Table 3 Adjusted association between physical activity scores (per SD increase) and odds of having $\geq 1,2,3$ CVD modifiable risk factor among Chinese adults

\begin{tabular}{|c|c|c|c|}
\hline & \multicolumn{3}{|c|}{ Adjusted Odds ratio (95 confidence interval) } \\
\hline & Having $\geq 1$ CVD modifiable risk factor & Having $\geq 2$ CVD modifiable risk factors & Having $\geq 3$ CVD modifiable risk factors \\
\hline Overall $^{a}$ & 0.98 (0.94 to 1.01$)$ & 0.96 (0.93 to 0.99$)$ & 0.93 (0.90 to 0.96$)$ \\
\hline \multicolumn{4}{|l|}{ Survey site ${ }^{b}$} \\
\hline Nanjing & 0.92 (0.86 to 0.99 ) & $0.95(0.90$ to 1.01$)$ & 0.90 (0.83 to 0.96$)$ \\
\hline Hefei & 0.98 (0.94 to 1.03$)$ & 0.96 (0.93 to 0.99$)$ & 0.93 (0.89 to 0.97$)$ \\
\hline \multicolumn{4}{|l|}{ Sex ${ }^{c}$} \\
\hline Male & 0.94 (0.87 to 1.01 ) & 0.93 (0.89 to 0.97 ) & 0.90 (0.86 to 0.94$)$ \\
\hline Female & 0.98 (0.93 to 1.03$)$ & 0.96 (0.93 to 0.99$)$ & 0.94 (0.90 to 0.99$)$ \\
\hline \multicolumn{4}{|l|}{ Age group ${ }^{d}$} \\
\hline$<35$ years & 0.99 (0.97 to 1.02$)$ & 0.92 (0.88 to 0.96 ) & $0.72(0.33$ to 1.57$)$ \\
\hline $35-44$ years & 0.97 (0.95 to 0.99$)$ & 0.97 (0.95 to 0.99$)$ & 0.93 (0.87 to 0.99$)$ \\
\hline $45-54$ years & 1.00 (0.97 to 1.03$)$ & 0.96 (0.94 to 0.98$)$ & 0.92 (0.87 to 0.98$)$ \\
\hline $55-64$ years & 0.95 (0.90 to 1.00$)$ & $0.98(0.96$ to 1.00$)$ & 0.97 (0.91 to 1.03$)$ \\
\hline $65-74$ years & 0.95 (0.89 to 1.01$)$ & 0.99 (0.98 to 1.00$)$ & 0.95 (0.85 to 1.06$)$ \\
\hline$\geq 75$ years & 0.68 (0.33 to 1.03$)$ & 0.89 (0.75 to 1.03$)$ & 0.54 (0.07 to 1.02$)$ \\
\hline
\end{tabular}

${ }^{a}$ indicates sex, survey site, and age group were adjusted; ${ }^{b}$ indicates sex and age group were adjusted; ${ }^{c}$ indicates survey site and age group were adjusted; ${ }^{\mathrm{d}}$ indicates sex and survey site were adjusted

The odds ratio was estimated by per SD ( 28 transformed Met Score) increase 
factors was insignificant in both gender; the adjusted OR of having $\geq 2$, and $\geq 3$ CVD modifiable risk factors were both significant in both genders. In the age-stratified analysis, the significant adjusted OR of having $\geq 1$ CVD modifiable risk factors was found in those aged 35-44 years; the adjusted OR of having $\geq 2$, and $\geq 3$ CVD modifiable risk factors was significant in those aged 35-44 years and those aged 45-54 years, respectively.

In Table 4, the adjusted OR of having $\geq 1, \geq 2$, and $\geq 3$ CVD modifiable risk factors for moderate physical activity group and high physical activity group was 0.88 (0.79 to 0.98 ) and 0.88 (0.79 to 0.99 ), 0.85 (0.78 to 0.92 ) and 0.85 (0.78 to 0.92$), 0.84$ (0.76 to 0.91 ) and 0.81 (0.74 to 0.89 ), respectively, with low physical activity as reference group. In the stratified analysis, the significant adjusted OR of having $\geq 2$ and $\geq 3$ CVD modifiable risk factors was found for moderate physical activity group and high physical activity group in each survey sample, and 35-44 and 45-54 age groups, respectively.

\section{Discussion}

Based on two independent surveys from two provinces in China, this study comprehensively examined the dose response associations of self-reported total physical activity and clustering of CVD modifiable risk factors among Chinese adults. Higher prevalence of clustering across CVD modifiable risk factors is associated with lower physical activity. The increase of the physical activity from < 600 MET-min/week to 600-3000 MET$\mathrm{min} /$ week is associated with 12, 15 and 16\% decreased odds of having $\geq 1, \geq 2$ and $\geq 3$ CVD modifiable risk factors. Although prevalence of each CVD modifiable risk factors was different over two surveys, the consistently similar findings are revealed in each survey. Improving physical activity among younger persons before the impacts of chronic disease become largely irreversible, could help to improve life expectancy.

Physical activity and single CVD modifiable risk factors in Chinese population have been addressed in prior studies. For example, Lao et al. identified inverse doseresponse association between leisure-time physical activity and diabetes risk as higher levels of leisure-time physical activity are associated with a lower risk of diabetes in Chinese people with impaired fasting glucose [16]. Yang et al. found that household physical activity was inversely associated with the risk of type 2 diabetes in among urban males in northern China [17]. Pang et al. reveals that higher physical activity is associated with lower concentration of atherogenic lipoprotein and cholesterol and lower levels of inflammation in Chinese

Table 4 Adjusted association between physical activity scores category and odds of having $\geq 1,2,3$ CVD modifiable risk factors among Chinese adults

\begin{tabular}{|c|c|c|c|c|c|c|}
\hline & \multicolumn{6}{|c|}{ Adjusted Odds Ratio (95\% confidence interval) } \\
\hline & \multicolumn{2}{|c|}{ Having $\geq 1$ CVD modifiable risk factor } & \multicolumn{2}{|c|}{ Having $\geq 2$ CVD modifiable risk factors } & \multicolumn{2}{|c|}{ Having $\geq 3$ CVD modifiable risk factors } \\
\hline & $\begin{array}{l}\text { Moderate physical } \\
\text { activity }\end{array}$ & $\begin{array}{l}\text { High physical } \\
\text { activity }\end{array}$ & $\begin{array}{l}\text { Moderate physical } \\
\text { activity }\end{array}$ & $\begin{array}{l}\text { High physical } \\
\text { activity }\end{array}$ & $\begin{array}{l}\text { Moderate physical } \\
\text { activity }\end{array}$ & $\begin{array}{l}\text { High physical } \\
\text { activity }\end{array}$ \\
\hline Overall $^{a}$ & 0.88 (0.79 to 0.98$)$ & 0.88 (0.79 to 0.99$)$ & 0.85 (0.78 to 0.92$)$ & 0.85 (0.78 to 0.92$)$ & 0.84 (0.76 to 0.91$)$ & 0.81 (0.74 to 0.89$)$ \\
\hline \multicolumn{7}{|l|}{ Survey site ${ }^{b}$} \\
\hline Nanjing & $0.83(0.68$ to 1.01$)$ & 0.79 (0.64 to 0.97$)$ & 0.75 (0.65 to 0.88$)$ & 0.71 (0.61 to 0.83 ) & 0.71 (0.60 to 0.84$)$ & 0.65 (0.55 to 0.78$)$ \\
\hline Hefei & 0.88 (0.77 to 1.01$)$ & 0.89 (0.78 to 1.01$)$ & 0.87 (0.79 to 0.96$)$ & 0.88 (0.80 to 0.96$)$ & 0.87 (0.78 to 0.96$)$ & 0.84 (0.76 to 0.93 ) \\
\hline \multicolumn{7}{|l|}{ Sex ${ }^{c}$} \\
\hline Male & 0.86 (0.78 to 0.96$)$ & 0.88 (0.73 to 1.03$)$ & 0.83 (0.63 to 1.02) & 0.81 (0.72 to 0.91$)$ & $0.82(0.60$ to 1.04$)$ & 0.80 (0.73 to 0.87$)$ \\
\hline Female & 0.99 (0.87 to 1.13$)$ & 0.97 (0.85 to 1.11$)$ & 0.97 (0.87 to 1.09$)$ & 0.98 (0.87 to 1.09$)$ & 0.93 (0.81 to 1.06$)$ & 0.95 (0.83 to 1.09$)$ \\
\hline \multicolumn{7}{|l|}{ Age group ${ }^{d}$} \\
\hline$<35$ years & 0.97 (0.30 to 3.09) & 0.67 (0.19 to 2.30$)$ & 0.27 (0.08 to 0.84$)$ & 0.51 (0.16 to 1.61$)$ & 0.26 (0.06 to 1.12$)$ & 0.33 (0.08 to 1.41$)$ \\
\hline $\begin{array}{l}35-44 \\
\text { years }\end{array}$ & 0.77 (0.65 to 0.90$)$ & 0.81 (0.69 to 0.95 ) & 0.69 (0.60 to 0.79$)$ & 0.70 (0.61 to 0.80$)$ & 0.71 (0.59 to 0.85$)$ & 0.69 (0.57 to 0.82 ) \\
\hline $\begin{array}{l}45-54 \\
\text { years }\end{array}$ & 0.76 (0.62 to 0.95$)$ & 0.77 (0.62 to 0.95$)$ & 0.77 (0.67 to 0.89$)$ & 0.82 (0.71 to 0.95$)$ & 0.76 (0.65 to 0.88$)$ & 0.69 (0.59 to 0.81 ) \\
\hline $\begin{array}{l}55-64 \\
\text { years }\end{array}$ & 0.92 (0.70 to 1.20$)$ & 0.96 (0.74 to 1.26$)$ & 0.98 (0.83 to 1.16$)$ & 0.96 (0.81 to 1.13$)$ & $0.87(0.74$ to 1.03$)$ & 0.90 (0.76 to 1.06 ) \\
\hline $\begin{array}{l}65-74 \\
\text { years }\end{array}$ & 0.65 (0.41 to 1.03$)$ & 0.84 (0.54 to 1.32 ) & 0.98 (0.76 to 1.28$)$ & 0.97 (0.75 to 1.27$)$ & 1.00 (0.78 to 1.29$)$ & 0.91 (0.70 to 1.17 ) \\
\hline$\geq 75$ years & 0.54 (0.09 to 3.62$)$ & 0.48 (0.09 to 2.54$)$ & $0.71(0.21$ to 2.38$)$ & $0.83(0.25$ to 2.76$)$ & $0.75(0.22$ to 2.56$)$ & 0.23 (0.06 to 0.95 ) \\
\hline
\end{tabular}

${ }^{a}$ indicates sex, survey site, and age group were adjusted; ${ }^{b}$ indicates sex and age group were adjusted; ${ }^{c}$ indicates survey site and age group were adjusted; ${ }^{d}$ indicates sex and survey site were adjusted

Adjusted odds ratio was estimated with low physical activity as reference group 
population [18]. Li et al. found higher level physical activity is related to between glycemic control and insulin sensitivity in southern Chinese population [19]. Similar with these findings, we identified inverse linear doseresponse relationship between higher total physical activity level and lower prevalence of having $\geq 1, \geq 2$ and $\geq 3$ CVD modifiable risk factors among Chinese adults. Instead of measuring parts of daily physical activity (i.e. leisure-time physical activity, sedentary time, or household physical activity), the overall activity measurement incorporating all parts of daily physical activity were undertaken in this study. And instead of investigating the single CVD modifiable risk factors, this study focused on the clustering status of CVD modifiable risk factors, which would generally reflect the individual CVD health and potential future CVD risk. In this study, about $15 \%$ decreased prevalence of having $\geq 2$ CVD risk factors might be avoided if the inactive individuals $(<<$ 600 MET-min/week) improved their physical activity to moderate level (600-3000 MET-min/week).

In this study, we investigated the dose-response association between physical activity and clustering of CVD modifiable risk factors not only in the general population but also in the different age-stratified subpopulation. The significant inverse association (higher prevalence of clustering across CVD modifiable risk factors is associated with lower physical activity) was identified in people aged 35-44 years. Among people aged less than 35 years, the insignificant association might suggest that physical activity might not take a significant role in the early onset of clustering of CVD modifiable risk factors [20], which of course need further validation in the external young populations. Among people aged more than 55 years, the existing comorbidities might take a significant role of the clustering of CVD modifiable risk factors [21], which would attenuate the contribution of physical activity. Based on this study, the health promotion programs including improving general physical activities should be advocated in the Chinese population aged 3554 by health policy makers.

Potential biological mechanism underlying the cardiovascular protective effects of physical activity against the clustering of CVD modifiable risk factors include some favorable modification effects in adiposity, insulin sensitivity, lipid profiles and systemic inflammation [16, 22-24]. Experimental studies also revealed that physical activity helps to improve body muscle mass and stimulates the uptake of glucose in muscles $[25,26]$ and reduce triglycerides and ceramides and improve insulin sensitivity [27].

As the strength of this study, overall $>90 \%$ response rate was achieved by this study, which made the study sample well represent local populations. The high response rate was achieved by household investigation and face-to-face interview by trained research staff. The limitation of this study is the utilization of cross-sectional survey datasets, whereby physical activity measurements and CVD modifiable risk factors were evaluated at same time. Therefore, it is impossible to process causal inference between physical activity and clustering of CVD modifiable risk factors. Future studies within in prospective cohort data would be the next step in testing above associations. Some other confounders like comorbidities (like existing CVD) could also alter the association between physical activity and clustering of CVD modifiable risk factors. However, more comorbidities more not available in this study. Finally, future external replication studies with adjustment of potential comorbidities, alongside meta-analysis are warranted to better understanding whether physical activity does have the potential modification role in the clustering of CVD modifiable risk factors. Some other blood markers that could confound the findings of this study, like Creactive protein were not accessible in this study and its confounding effect could not be addressed in this study. Instead of using International Physical Activity Questionnaire to assess physical activity, accelerometers or other wearables might be preferred in recent studies. Future replication studies using wearables to assess physical activity are warranted.

\section{Conclusion}

In conclusion, in Chinese adults, physical activity level inversely associates with clustering of CVD modifiable risk factors, especially in Chinese adults aged 35 to 54 years. Health promotion programme including improve physical activity level should be advocated. Physical activity has the potential modification role in the clustering of CVD modifiable risk factors that warrants further validation in the future prospective cohort studies.

\section{Abbreviations \\ CVD: Cardiovascular diseases; CVDMRF: Clustering of cardiovascular diseases modifiable risk factors; MET: Metabolic equivalent task; BMI: Body mass index; SBP: Systolic blood pressure; DBP: Diastolic blood pressure; OR: Odds ratio; Cl: Confidence interval}

\section{Acknowledgements}

We are also grateful to all the individuals who conducted the data collection and entry.

\section{Authors' contributions}

RS, YY, YC, and DY designed the study. RQ, YC, and DY collected the data. $R S, Y C$ and DY conducted the data analyses. RS, YC, RQ, YY and DY drafted the manuscript. RS, YY, YC, RQ and DY edited the manuscript. All authors have read and approved the final manuscript.

\section{Funding}

This work received supports from the National Natural Science Foundation of China (grant number 81800299). The funder had no role in the design of the study and collection, analysis, and interpretation of data and in writing the manuscript.

\section{Availability of data and materials}

The data used and/or analyzed during the study are available from the corresponding author on reasonable request. 


\section{Ethics approval and consent to participate}

Ethics approval of this study was acquired from the Institutional Review Board of Jiangsu Province Hospital on Integration of Chinese and Western Medicine (approval number 11-006). Signed, Informed consent was obtained from all study participants.

\section{Consent for publication}

Not applicable.

\section{Competing interests}

The authors declare that they have no competing interests.

\section{Author details}

'Department of Cardiovascular Medicine, The First Affiliated Hospital of Xi'an Jiaotong University, Xi'an 713300, China. ${ }^{2}$ Jiangsu Province Hospital on Integration of Chinese and Western Medicine, Nanjing 210028, China. ${ }^{3}$ Department of Cardiovascular surgery, The First Affiliated Hospital of Xi'an Jiaotong University, Xi'an 713300, China. ${ }^{4}$ Primary Care Centre Versus Arthritis, School of Primary, Community and Social Care, Keele University, Keele ST5 $5 B G, U K$

Received: 19 March 2020 Accepted: 17 July 2020

Published online: 25 July 2020

\section{References}

1. Zhu J, Yu X, Zheng Y, Li J, Wang Y, Lin Y, He Z, Zhao W, Chen C, Qiu K, Wu J. Association of glucose-lowering medications with cardiovascular outcomes: an umbrella review and evidence map. Lancet Diabetes Endocrinol. 2020.

2. Moran A, Gu D, Zhao D, Coxson P, Wang YC, Chen CS, Liu J, Cheng J, Bibbins-Domingo K, Shen YM, He J, Goldman L. Future cardiovascular disease in China: markov model and risk factor scenario projections from the coronary heart disease policy model-China. Circ Cardiovasc Qual Outcomes. 2010;3(3):243-52.

3. Gu D, Gupta A, Muntner P, Hu S, Duan X, Chen J, Reynolds RF, Whelton PK, He J. Prevalence of cardiovascular disease risk factor clustering among the adult population of China: results from the international collaborative study of cardiovascular disease in Asia (InterAsia). Circulation. 2005;112(5):658-65.

4. Qin L, Corpeleijn E, Jiang C, Thomas GN, Schooling CM, Zhang W, Cheng KK, Leung GM, Stolk RP, Lam TH. Physical activity, adiposity, and diabetes risk in middle-aged and older Chinese population: the Guangzhou biobank cohort study. Diabetes Care. 2010;33(11):2342-8.

5. Lee IM, Shiroma EJ, Lobelo F, Puska P, Blair SN, Katzmarzyk PT, Lancet physical activity series working group. Effect of physical inactivity on major non-communicable diseases worldwide: an analysis of burden of disease and life expectancy. Lancet. 2012;380(9838):219-29.

6. Yu L, Cai Y, Oin R, Zhao B, Li X. Association between triglyceride glucose index and abnormal liver function in both urban and rural Chinese adult populations: findings from two independent surveys. Medicine (Baltimore). 2019;98(50):e18265.

7. Yu D, Chen T, Qin R, Cai Y, Jiang Z, Zhao Z, Simmons D. Association between lung capacity and abnormal glucose metabolism: findings from China and Australia. Clin Endocrinol. 2016;85(1):37-45.

8. Yu D, Chen T, Cai Y, Zhao Z, Simmons D. Association between pulmonary function and renal function: findings from China and Australia. BMC Nephrol. 2017;18(1):143-017-0565-y.

9. Yu D, Yang W, Chen T, Cai Y, Zhao Z, Simmons D. Hypertriglyceridemicwaist is more predictive of abnormal liver and renal function in an Australian population than a Chinese population. Obes Res Clin Pract. 2018; 12(5):438-44.

10. Chobanian AV, Bakris GL, Black HR, Cushman WC, Green LA, Izzo JL Jr, Jones DW, Materson BJ, Oparil S, Wright JT Jr, et al. The seventh report of the joint National Committee on prevention, detection, evaluation, and treatment of high blood pressure: the JNC 7 report. JAMA. 2003;289(19):2560-72.

11. 1999 World Health Organization--International Society of Hypertension Guidelines for the Management of Hypertension. Guidelines sub-committee. Blood Press Suppl. 1999:1:9-43.

12. Gu D, Reynolds K, Wu X, Chen J, Duan X, Reynolds RF, Whelton PK, He J, InterASIA collaborative group. Prevalence of the metabolic syndrome and overweight among adults in China. Lancet. 2005;365(9468):1398-405.
13. Yu D, Huang J, Hu D, Chen J, Cao J, Li J. Is an appropriate cutoff of hypertriglyceridemic waist designated for type 2 diabetes among Chinese adults? Clin Nutr. 2010;29(2):192-8.

14. Lear SA, Hu W, Rangarajan S, Gasevic D, Leong D, Iqbal R, Casanova A, Swaminathan S, Anjana RM, Kumar R, Rosengren A, Wei L, Yang W, Chuangshi W, Huaxing L, Nair S, Diaz R, Swidon H, Gupta R, Mohammadifard N, Lopez-Jaramillo P, Oguz A, Zatonska K, Seron P, Avezum A, Poirier P, Teo K, Yusuf S. The effect of physical activity on mortality and cardiovascular disease in 130000 people from 17 high-income, middleincome, and low-income countries: the PURE study. Lancet. 2017; 390(10113):2643-54.

15. Oyeyemi AL, Moss SJ, Monyeki MA, Kruger HS. Measurement of physical activity in urban and rural south African adults: a comparison of two selfreport methods. BMC Public Health. 2016;16(1):1004 -016-3693-6.

16. Lao XQ, Deng HB, Liu X, Chan TC, Zhang Z, Chang LY, Yeoh EK, Tam T, Wong MCS, Thomas GN. Increased leisure-time physical activity associated with lower onset of diabetes in 44828 adults with impaired fasting glucose: a populationbased prospective cohort study. Br J Sports Med. 2019;53(14):895-900.

17. Yang J, Zhang YL, Ye J, Guo Q, Sun YN, Zeng Q. Association between household physical activity level and type 2 diabetes among urban males in northern China. Public Health. 2018;163:113-20.

18. Pang Y, Kartsonaki C, Du H, Millwood IY, Guo Y, Chen Y, Bian Z, Yang L, Walters R, Bragg F, Lv J, Yu C, Chen J, Peto R, Clarke R, Collins R, Bennett DA, Li L, Holmes MV, Chen Z. Physical activity, sedentary leisure time, circulating metabolic markers, and risk of major vascular diseases. Circ Genom Precis Med. 2019;12(9):386-96.

19. Li L, Yin X, Yu D, Li H. Impact of physical activity on glycemic control and insulin resistance: a study of community-dwelling diabetic patients in eastern China. Intern Med. 2016;55(9):1055-60.

20. Rees R, Kavanagh J, Harden A, Shepherd J, Brunton G, Oliver S, Oakley A. Young people and physical activity: a systematic review matching their views to effective interventions. Health Educ Res. 2006;21(6):806-25.

21. McPhee JS, French DP, Jackson D, Nazroo J, Pendleton N, Degens H. Physical activity in older age: perspectives for healthy ageing and frailty. Biogerontology. 2016;17(3):567-80.

22. Panagiotakos DB, Pitsavos C, Chrysohoou C, Kavouras S, Stefanadis C. ATTI CA study: the associations between leisure-time physical activity and inflammatory and coagulation markers related to cardiovascular disease: the ATTICA study. Prev Med. 2005;40(4):432-7.

23. Vuori IM. Health benefits of physical activity with special reference to interaction with diet. Public Health Nutr. 2001;4(2B):517-28.

24. Bassuk SS, Manson JE. Epidemiological evidence for the role of physical activity in reducing risk of type 2 diabetes and cardiovascular disease. J Appl Physiol (1985). 2005;99(3):1193-204.

25. Richter EA, Hargreaves M. Exercise, GLUT4, and skeletal muscle glucose uptake. Physiol Rev. 2013;93(3):993-1017.

26. Cartee GD. Roles of TBC1D1 and TBC1D4 in insulin- and exercise-stimulated glucose transport of skeletal muscle. Diabetologia. 2015;58(1):19-30.

27. Bird SR, Hawley JA. Update on the effects of physical activity on insulin sensitivity in humans. BMJ Open Sport Exerc Med. 2017:2(1):e000143.

\section{Publisher's Note}

Springer Nature remains neutral with regard to jurisdictional claims in published maps and institutional affiliations.

Ready to submit your research? Choose BMC and benefit from:

- fast, convenient online submission

- thorough peer review by experienced researchers in your field

- rapid publication on acceptance

- support for research data, including large and complex data types

- gold Open Access which fosters wider collaboration and increased citations

- maximum visibility for your research: over $100 \mathrm{M}$ website views per year

At $\mathrm{BMC}$, research is always in progress.

Learn more biomedcentral.com/submission 